\title{
Other Places and The Caretaker: An Exploration of the Inner Reality in Harold Pinter's Plays
}

\author{
Hongwei Chen \\ School of Foreign Studies, Beijing University of Science and Technology, Beijing, China
}

\begin{abstract}
Exploring in his plays an overlapping area where social forces and human instincts interplay and superimpose upon each other, Harold Pinter dramatizes the inner reality of the characters who are trapped in various ambivalent forces, which collide and conflict, thereby producing the paradoxical tension in the subject's instinct of escape and impulse to stay within.
\end{abstract}

Index Terms - man in modern society, the realm of "the real", other places, inner reality

\section{INTRODUCTION}

If we examine Harold Pinter's plays from The Room (1957) to Moonlight (1993), we may find that, however diversified the themes may appear (politics, family, or gender), two narrative models always can be found in them. In the first model, an individual escapes from various forms of "rooms" (either a mysterious club, or family, or the Establishment) and is hounded, seized, interrogated and tortured for his attempt to be a non-conformist. Such characters as Stanley in The Birthday Party (1958), the son in Family Voices (1982), Victor in One for the Road (1984), as well as Fred and Jake in Moonlight, all belong to this category. In the second type of structure, characters are presented within various rooms, to which the characters cling as their territories. They are faced with not only threat from outside, but also menace from within. This group of "room plays" covers almost all of Pinter's works whose setting is a room, ranging from The Room, The Caretaker (1960), Old Times (1971) and Party Times (1991). Together, the two kinds of dramatic modes in Pinter's plays compose the duality of the essential living reality of human beings that Pinter intends to present. The central image of "room" works both as a shelter and a confinement to individuals. It is the realm where the exterior social force and the internal private voice interact and collide. To those who pursue the utterance of their private voice, the room is a confinement they feel irritated with; to those who play the game along social rules, the room is a territory they fight for. What Pinter presents is the characters trapped in the discrepancy between outside social forces and the internal private voice, i.e., a situation which is similar to the realm of "the Real" in Jacques Lacan's theory.

This can be particularly shown in his triple bill of Other Places and the early classic, The Caretaker.

\section{LACAN’S REALM OF “THE REAL”}

According to Lacan, men undergo two important stages in their infant phase: the Mirror stage and the Symbolic stage. Every infant goes through a mirror phase, in which he ("le petit homme") gets identified with a coherent and selfgoverning entity through mirror or his mother. Lacan also calls this pre-linguistic, pre-Oedipal stage the realm of the "Imaginary," which is a metaphor of Freud's narcissism. The importance of this stage is that before the infant experiences itself as a shapeless mass, it gains a sense of wholeness, an ideal completeness, by modeling itself upon the mother. In this fantasy of completion, there is no gap for the child between a concept and its application because the child's desire for the mother is identified with the desire of the mother. Here, what is the most important is, as Malcom Bowie (1987) points forth, this moment of self-identification "represents a permanent tendency of the individual: the tendency that leads him throughout life to seek and foster the imaginary wholeness of an 'ideal ego"' (pp. 105-6).

When the child begins to learn to speak, he starts a process of entering into the Symbolic order, a domain of "the paternal signifier" (Holland, 1999, p.47). The structures of language are marked with social imperatives-the Father's definitions, orders, laws and taboos. To Eugene W. Holland (1999), this transformation is like "the Oedipus complex""losing touch with the physical realm of bodily substance or 'being' ... and accepting the realm of meaning and the law of signification in its place" (p.47). In the words of Sean Burke (1998), the subject can enter into the signifying chain of language, the symbolic system of differences and arbitrary identifications through which (for Lacan) all human society is constructed, only through losing its pre-linguistic state of imaginary oneness.

Compared with the Imaginary Order, a feature of the Symbolic order is the facet of lack or gap. Concerning this point, Holland (1999) explains,

The illusory sense of wholeness produced by Imaginary identifications in the mirror-stage is then compounded by the subject's entry into the Symbolic Order of language, within which the fledgling ego has long since been assigned a place through the imprimatur of a proper name.... The speaking subject henceforth, according to Lacan, lacks access to its own body, lacks the ability to grasp or express its substantial being in the only means made available to it: 
differential language. (p.50)

The gap appears when the illusory sense of the wholeness formed in the mirror stage is shattered by the subject's entry into the symbolic order of language where the ego is assigned a place through names. In that way, entering the realm of language, the child also enters the world of "the other," which "introduces a gap between desire and its object(s) which the subject is bounded by," and makes man a "unified ego" based on lack. In this respect, the Other, which introduces "gap" and "lack" into the operation of the subject, "provides an essential precondition for the humanity of man" (Bowie, 1987, p.119). Burke (1998) once made a vivid summary of the change of Lacan's subject: he "moves from the (pre-Oedipal, imaginary) realm of the 'I am' through the 'I think' only to discover that 'it is not where I think" (p.100).

What Pinter tries to present in his plays is just the dramatic tension of "it is not where I think" - a tension and the "gap" that we social beings are born into between the tendency of seeking the imagery wholeness and the "perpetual flight of the goals of desire" (Bowie, 1987, p.117). Or, we may say, it is a realm that is like Lacan's "the Real." But the difference between Pinter and Lacan in this respect is that Lacan is philosophical and psychological, while Pinter's concern is the human reality of existence. "The Real" in Lacan's theory is an overlapping, interacting and conflicting area where both the Imaginary and the Symbolic voices are found in operations. In this realm, as Elizabeth Wright (1984) illustrates, "Language [social voice] imposes a chain of words along which the ego must move while the unconscious remains in search of the object it has lost" (p.111). In a similar way, what Pinter dramatizes and explores is the inner reality of the characters who are liable to the influence of the two voices - the social and the private-which collide and conflict, thereby producing the paradoxical tension in the subject's instinct of escape and impulse to stay within. While the social force intends to impose its dominating, signifying and regulating power on the subject, the private impulse constantly reminds him of the gap between his desire and what the social order offers, and of the pain of the forever difference and ineffable displacement. It is in this attempt to seize the inner truth in the profound psyche of modern men that Pinter's work demonstrates another kind of duality in his artistic approach.

\section{Men in the "Other Places"}

In Pinter's plays, his characters are frequently trapped in a painful state of "lack": no matter how powerful a figure is in society, he seems to cherish a dream that belongs to some place in the past, and is locked in the difference between the dream and the reality. In The Caretaker, the tramp frequently mentions his attempt to go to Sidcup to seek a certain document that can prove his identity; and the two brothers in the same play also have their own respective dreams (while Aston's is to build a shed in the ruined garden, Mick is to redecorate the family house); in Old Times, Kate's dream appears in a form of memory of the "old times"; in Betrayal, the audience finds Emma and Robert locked in their memories about the past. And even such villains as McCann and Goldberg in The Birthday Party carry some dreams despite their brutality: McCann's is Paddy Reilly that brought him the Garden of Eden and Goldberg's is a memory of his father's words about the world. Sometimes, the dream may take the form of the characters' attempt to seek a substitute self or home as what happens in The Homecoming, Family Voices and Moonlight. No matter what forms the "substitute home" takes - either the home the son finds for himself in Family Voices, The Homecoming, and Moonlight, or the apartment rented by Emma and Jerry for their extra-marital affairs - it represents a certain pursuit of the characters. To the "sons" and dissenters, the new home embodies their pursuit of their individuality; to the female figures like Kate and Emma, it represents their ideal of free womanhood and marital expectations.

In each image of Pinter's plays, people can perceive the characters' impulse to seek and foster the imaginary wholeness of an "ideal ego" in Lacan's theory. This image of dream and substitute home is actually an ego's attempt to search for the self-identity in the social world of the language that imposes compulsory laws and taboos on him. So, to Pinter's characters like Stanley in The Birthday Party, the real terror "is not just that he is destroyed as he is led away at the end of the play, but that he is also destroyed if he remains, that if 'It's no good here' and no good out there in the world of Monty, then truly, as Stanley remarks to Lulu, 'There's nowhere to go"' (Hale, 1986, p.38). It is true indeed that in most cases, the hounded victims usually end their attempt to seek freedom in a frustration or cynical attitude of taking life as a game (as what the two sons do in Moonlight), that is, to end in a failure to find the ideal "home" or "room" they want.

What Pinter tries to explore is just the complicated and contradictory feelings of man trapped in the duality of running on the road with a furtive glance behind his back, or staying in the "substitute home" (chosen by himself) but being troubled constantly by the voice of the "real home", i.e., trapped in the feeling of "other place" and gap. Among all his works, the idea of the "Other Places", the triple bill formed by Victorian Station, Family Voices and A Kind of Alaska, illustrates most effectively the trapped state of men in modern society.

In the short play of Victorian Station, for instance, the dramatic portrayal of the contradictory relationship between the controller and the driver exemplifies the pattern in the three plays and the general situation of man in society as a whole. The opening scene of the controller sitting at microphone in the lit-up office with the driver cruising somewhere on the road immediately paints a symbolic picture of the man in the society. Facing the call from the controller in the "lighthouse", the individual man feels both controlled by the director and lost on his own road. The controller wants the driver to go to Victorian Station to meet a customer there and then send him to Cuckfield. When he says, "I am just talking into this machine, trying to make some sense out of our lives. That's my function. God gave me this job...I'm 
your local monk" (p.198), the controller assures his identity clearly as the role of Lacan's "paternal metaphor": the father-figure of the nuclear family, kings, despots, gods and all other things or figures that work in the social voice of defining, naming, prohibiting and controlling. The dilemma and psyche of the driver invites audience to think of Lacan's confused subject who is forever struggling in the displacement caused by the "gap". On the one hand, the driver declares that he is lost and does not know what he has been doing all these year; but on the other hand, when the controller is to give him up for another driver 135, he is scared. He shouts: "Don't leave me. I'm your man. I'm the only one you can trust" (p.202). The driver's paradoxical response to the controller is the same with other characters' feelings towards "room", from which they try to escape and to which they also cling. Eventually the controller's angry voice, like a thunder from God, makes the driver know his location: "I'm sitting by a little dark park underneath Crystal Palace" (p.203). At the same time, the audience also sees the same contradictory situation on the side of the controller: his dominating posture to the driver is equally matched with a reliance on the cooperation of the individual components that form its very texture of power: "I'd like you to come with me...we can swim together in the blue Caribbean" (p.208). But by this time, the driver has found the "true love": she is asleep on the back seat. The play ends in the paradoxical state of the driver who roams with an awareness of the controller's voice but cherishes the private faith in the "woman" on his back seat. The dilemmatic state of the driver is echoed later in the next play in the triple bill, Family Voices, in which the son struggles in the predicament between an old home (dominated by his parents) and a new one (chosen by himself).

If the Victorian Station and Family Voices portray a man's dilemma in the society, A Kind of Alaska, the third one in Other Places, depicts the frustrating and painful experience of man's (the ego with an illusionary wholeness of selfidentification) transplanting of himself into the Symbolic order of language, where an authentic voice of "father" awaits to deny all that once belonged to his existence and to relocate himself.

A kind of Alaska is the only play by Pinter that is inspired by another writer's work-Awakenings by Oliver Sacks. It tells the moment when a woman who has slept for decades wakes up after an injection from the doctor, her sister-in-law who has nursed her in all those years. The whole play, built on the dialogues between the woman, Deborah, and the doctor, Hornby, and can almost be read as a dramatic moment of "the Real" in Lacan's theory: the moment when the subject transfers from his private world into the social one. The initial image of "A woman in a white bed" suggests a pure state of wholeness in the Imagery Order of Lacan's. When the play begins, as the first sentence tells, "Something is happening" (p.155). The repetition of the same sentence in the following moment suggests the confusion and horror of the dazzled speaker when suddenly falling into a totally strange world. As soon as the two characters begin to talk, their discourse immediately betrays the difference of what they represent:

DEBORAH: Do you recognize me?

Silence

HORNBY: Do you know me?

Silence.

Can you hear?

She does not look at him. (pp. 153-4)

While she uses the word, "recognize" to suggest an identity that belongs to the past, Hornby's sentences of "Do you know me? Can you hear?" imply a present world of existence that she is expected to know and accept. Since this moment, they two develop their dialogue by following their respective discourses: Hornby's is to follow the signifying social language, while Deborah's is to pursue a private one.

What they express reveals their respective characteristics. What the doctor stresses is the importance of "name" "Do you know who I am?" (p.154) — that is, the social function of language, "which represents the subject for another signifier" (Bowie, 1987, p. 200). Through his talk, he tries to transplant and locate this newly awakened woman in the patriarchal realm of names, facts, concepts and reason. As he tells her: "I would like you to listen to me. (Pause.) You have been asleep for a very long time. You have now woken up.... You are still young, but older" (p.155). He tries hard to let her accept the basic facts and concepts that make the world what it is: time, age, and the living state in the past years. But in most of his talk with her, he is assuming the paternal tone to correct her confusions and put her into the right order:

DEBORAH: ...Tell her [Deborah's sister] not to marry him. She'll listen to you. (Pause.) Daddy?

HORNBY: She didn't marry him.

DEBORAH: Didn't? ...

HORNBY: She didn't marry him.

DEBORAH: But you mean I've been dead?

HORNBY: If you had been dead you wouldn't be alive now.

DEBORAH: Are you sure?

HORNBY: No one wakes from the dead. (pp. 159-64)

Here, while she insists on thinking on the basis of her memory, he keeps on resetting a new logic of reason and facts into her mind.

In contrast with Hornby's attempts to relocate her into the "normal world" of the paternal language, Deborah clings 
desperately to the Alaska world of white wholeness in memory, struggling painfully for a standing point. From the beginning, she has kept on resisting his attempt to impose various facts on her conscious by seeking a refugee in her past world. So when he asks her, "Who am I," she answers, "You are no-one" (p.155). Instead, she lingers in her own familiar realm which has its own "language": "What language am I speaking? I speak French, I know that. Is this French? (Pause.) I've not seen Daddy today. He's funny...we play with balloons" (p.156). If the paternal authority and the factual concepts are the features of Hornby's social system, then the maternal authority and the bodily impulse are the facets of Deborah's world of "sleep": "If I sleep late my mother wakes me up....You shouldn't have brought me here. My mother will ask me where I've been. (Pause.) You shouldn't have touched me like that. I shan't tell my mother" (pp.157-8). Here, she tries to use the authority of her "Mummy" to fight against the imposing reality of the present: "If I have been asleep, why hasn't Mummy woken me up?"(p.157). She makes it clear that she lives in a world of the body instead of that of concepts or morality: "it was my lust made me cry. You are a devil. My lust was my own. I kept it by me" (p.161). And she uses her law of the body to justify her behavior: "What's wrong with that? ... Why do you blame me? I was simply obeying the law of the body" (p.163). The shift from her familiar realm of "Mummy" and the "law of the body" to his world of names, facts and concepts suggests a transfer, which is similar to Lacanian transition from the mirror phase to the symbolic one- "Separation from the mother means losing touch with the physical realm of bodily substance or 'being'... and accepting the realm of meaning and the law of signification in its place" (Holland, 1999, p.47).

Here, the strongest feeling revealed in the dialogue between these two figures is Deborah's sense of gap when facing the social realm that Hornby imposes on her: "Asleep? (Pause.) I do not remember that.... Where is everyone? Where is my dog?" When she tells Hornby, "What room is this? It's not my bedroom. My bedroom has blue lilac on the walls. The sheets are soft, pretty. Mummy kisses me. (Pause.)" (pp.157-9), she is not merely talking about a bedroom, but rejecting the fact of change and the dislocation brought by it. The significant point here is that while she resists his imposed realm of facts, she also tries simultaneously to adjust herself to the new system - because gradually she comes to raise questions and link them with her world. Nevertheless, being trapped in this sense of "gap", Deborah's feeling to the new world is one of confinement. As she says, "I've obviously committed a criminal offence and am now in prison. I'm quite prepared to face up to the fact. But what offence? ... such a terrible sentence"(p.166). Throughout the play, she moves back and forth between her world of the past and his of the present. For a moment, she tries to achieve a balance by identifying him with the prince in her fairy tales, but this attempt crashes in front of his cool masculinity of reason and law:

DEBORAH: Or did you no not wake me up? Did I just wake up myself? All by myself? Or did you wake me with a magic wand?

HORNBY: I woke you with an injection.

DEBORAH: And you are my Prince Charming. Aren't you? ...I think I love you.

HORNBY: No, you don't. (pp. 168-9)

Deborah's insistence on identifying herself with the sleeping beauty exemplifies the life-long tendency of the ego's seeking for wholeness; the picture of the whole family laughing at the dinner table when she fell into the long sleep foregrounds the sense of loss of the ideal.

When Deborah's sister, Pauline, appears in front of her, the final moment of entering the social world of Hornby's paternal language comes at last. With the sister's image of suffering and her story of their devotion to Deborah and her half-true and half-false account of the family, she introduces to Deborah other essential features of the language world: the moral principles of loyalty and the concept of truth and lies, thereby bringing the picture of the social world to its fullest form. It also pushes Deborah's painful journey of self-transplantation to the end. When Deborah says in a lamenting tone, "I must be quite old. I wonder what I look like... You say I have been asleep...You say I am a woman ...Mummy and Daddy and Estelle are on a world cruise.... I think I have the matter in proportion" (pp.189-90), the world she accepts here is one of both truth and lies: the truth is that she has been asleep for many years; the lie is that the family is not on a world cruise, but is in a bleak state with the mother dead, the father blind and the oldest sister wretched in marriage. Reading the play in this way, the image of the approaching birthday party for Deborah is indeed a hallmark of her new birth: the birth into the world of social orders.

Deborah's feeling of "gap" and "other" is of course not her own. Most of Pinter's characters suffer the same discrepancy between the dream in the past and the reality of the present. The dramatist seems to know it well himself. He once suggested that there are two Pinters: the private one in his "no man's land" of plays where he is bothered by nothing else outside, and the public one. And sometimes, he feels trapped by this kind of duality. In a 1971 interview with Gussow, Pinter (1994) said,

HP: I think I am in a trap, always. I sometimes wish desperately that I could write like someone else, be someone else.... You're trapped with yourself all your damned life....I must admit that I also tend to get quite exhausted about being this Harold Pinter fellow. This is quite apart from being me. Harold Pinter sits on my damn back.

MG: Who's Harold Pinter?

HP: He's not me. He's someone else's creation. It's very curious. (p.25)

As Pinter's school friend, Goldstein, recalls their early experience of feeling the gap: "I recall Harold Pinter quoting 
Cardinal Newman to me about the creation being a vast aboriginal calamity. I never forgot the phrase because it seemed to me beneath the surface of our talk lay the empty, gaping black hole which for me Schubert-and much later, Beckettknew all about." (Billington, 1996, p.13) About Goldstein's recollection, Billington (1996) comments, "If Goldstein never forgot the phrase, neither did Pinter. The notion that beneath the surface of daily existence lie desolation and emptiness permeates his work..." (p.13). The sense of difference between the highly private and stimulating feeling about the life they experienced in art and the ordinary life they led in reality must have been Pinter's earliest awareness of the profoundly black hole in life that could never be touched and filled up.

\section{Men CAUGht In InEFFable Forces}

It is the double act in the inner world that Pinter's plays try to dramatize and present. Being eternally trapped in the false balance (which is actually a gap and lack) between the social voice of the arbitrary signifiers and the ego's instinctive voice for an imagined wholeness, Pinter seems to suggest in his works that man is doomed to struggle forever in the confusion. And the two images of the "other place" and "the room" where Pinter's characters are snared reflect vividly their contradictory forces in their psyche. Here, we might take The Caretaker, a typical "room" play, as an example to examine how Pinter presents the inner reality of the men caught in the ineffable forces.

There are three characters in the play: two brothers, Aston and Mick, and a tramp that Aston brings to the flat. The flat belongs to the younger brother, Mick, though he does not live there. He entrusts his older brother, Aston, to redecorate it. The moment the tramp is brought to the room, he begins to covet it as a shelter of security. Being mild and quiet, Aston has been offering things to Davies throughout the play—seat, cigarette, shoes, bed, key to the flat, jacket, and finally the job as a caretaker. As a contrast, Mick is both violent and cunning. In the whole play, he is trying his best to drive the tramp from the exclusive world of the brothers. But as the dominating image of the bucket hanging under the roof suggests, there is clearly a certain kind of breach between the brothers. Soon, Davies begins to play the dangerous game of using Mick to repel Aston who, he discovers, once suffered psychiatric trouble. After repeated conflict between Aston and Davies over the window and the bed, Aston asks the tramp to leave.

The Caretaker is traditionally seen as a comedy of menace, in which characters fight for their territory. Many critics focus their attention on Davies, the tramp, and their opinions are mainly unfavorable: in the eyes of Billington, for instance, Davies is “a blustering, belligerent, selfish imposer" (Page, 1993, p.26) while in Benedict Nightingale's (1981) views, Davies "has not one atom of good in his make-up. He's a complete liar, bully and manipulator" (1981, 11). But critics can not deny the fact that "Tramp has always been popular with audience" (p.11). Repellent as Davie is in his manipulation and aggression, the audience still cannot help sympathizing with him. In fact, Davies is a typical Pinteresque figure, a pitiful figure trapped in the human predicament rather than a real villain. To a certain degree, he might stand for the universal dilemma of man in society as a whole, and the film version of the play reveals this point more explicitly than the stage one. ${ }^{1}$

A great change from the stage play to the film of The Caretaker is that seven exterior scenes are introduced into the former exclusive "room" story: Davies is shown to come from the road into the room when the story begins. This emphasizes his situation as one who is trapped between the world of the street and the interior realm of room, and a man locked in the threshold state of the permanent gap and loss.

In the play, Davies is the character who arouses the most mixed feelings in the audience. The exterior scenes introduced by the camera accent the trampled and deprived image of Davies on the street or in the society that was only implied in the stage play. When the film begins, the audience sees how Aston brings Davies from the world of the street to the flat. While they walk on the snowy and bleak street, Davies talks to the silent Aston about the rough experience of being kicked out from the place he worked when he refused to take a bucket of rubbish out. And from his talk we know that this kind of things happened frequently to him in the past years on the road. In the seven exterior scenes, four are about Davies. Aside from the first scene mentioned above, another scene sees Davies stumbling in the snowstorm, begging to a person passing by. In the third scene, we find him on the street alone in the bleak morning when Mick invites him to a drive to Sidcup, only to drop him on the same spot a few minutes later. This scene not only shows the miserable situation of Davies, but the picture of Mick dropping Davies on the same spot after driving a circle shows symbolically how life has worked like a pipe dream to the tramp: a doomed circle of having dreams and of those dreams being crushed. Beginning with Davies being brought into the flat one night and ending with his eviction into the street on another night, the play demonstrates effectively how life is forever a futile game of "loss", in which he is forever a "tramp." Moreover, the exterior scenes not only give a realistic sense to the story as many critics suggest, but also explain the cause of the character that is shown more explicitly later in the play. Davies has been made what he is in life - he is the victim of the discrepancy between what he yearns for and what he finds, a victim of the eternal "gap." In the play, everything he finds turns out to be not what he expects - the cigarette, the shoes, the bag, jacket, position as a caretaker, and the "room" as a "home." Everything comes and then goes-he seems to be on an eternal threshold of gain and loss. The image of Davies habitually punching his hands and the gesture of boxing emptily as if constantly fighting against certain rivals in the air signify vividly how hard he struggles to grab the forever-differential things in

\footnotetext{
${ }^{1}$ The film version of The Caretaker was released in 1964, four years later after the stage performance. It had Clive Donner as its director, and Alan Bates and Robert Shaw, the actors for Mick and Aston on the stage, still performing the two roles. The most important point is that Pinter re-wrote the script on the basis of the former stage script with moderate changes, and took part in the whole process of filming.
} 
life.

But here, Pinter's attention is not on the social significance reflected in Davies. Like the stage play, what the film version explores is the inner world of the man: how a man tries painstakingly to enter a "room" and how he, once in it, tries to possess it as his territory. The fatal flaw in Davies' character is that pitiful as he is in life, he demonstrates the nastiest qualities of human nature: arrogance, greed and bullying. He is on the constant threshold of being trampled and trampling others. The very moment when he is offered something and gets relieved from the victim position, he is unconsciously assuming the role as a repulsive bully and tries to manipulate the person who helps him. This can best be shown in his relation with Aston.

In the play, there are two scenes in which Aston offers Davies a pair of shoes. In both cases, Davies declares the shoes are not "suitable" for him. In the several minutes after Aston makes the first offer, the screen shows how Aston sits on the bed rubbing the shoes for him while the old man walking around him, throwing his hands, telling excitedly of a story of how a "bastard monk" did not give him a proper pair of shoes. Through the whole process, the camera gives a sequence of close-up shots: with Aston sitting on the bed and Davies moving dominatingly in front of the camera. With such shots, the camera frequently catches a symbolic relationship between the two figures: though Aston is still sitting on the "bed" (the "bed" works like the "chair" in The Homecoming as the symbol of power in the "room"), Davies's moving figure and his comparatively standing posture give people a subtle sense of threat. Moreover, while he moves restlessly, his torrents of grumbling about the "monk" is mixed with his reference to the shoes Aston finds. The whole effect is violent enough to disturb any audience:

Can't wear shoes that don't fit. Nothing worse. I said to this monk, here, I said ...I said, you haven't got a pair of shoes, have you, a pair of shoes, I said, enough to keep me on my way. Look at these, they're nearly out, I said, they're no good to me. I hear you got stock of shoes here. Piss off, he said to me. Now look here, I said, I'm an old man, you can't talk to me like that...I said, what do you think I am, a wile animal? What about them shoes I come all the way here to get I heard you was giving away? I've a good mind to report you to your mother superior. (p.14)

The monk that Davies decries so bitterly in his speech reminds people of the solitary and hermitic Aston who is rubbing the shoes for him: this association immediately throws some light on the tramp's real intention in telling the story. The monk he grumbles of so menacingly must be another imagined Aston in his mind. By condemning the monk's failure to give him a pair of proper shoes, he is actually protesting to the person who is offering an equally unsatisfactory pair of shoes to him.

Near the end of the play, Aston offers another pair of shoes to Davies - the last offer he makes. By this time, the scene has been changed. In the frame of the shot, it is not Aston but Davies who is sitting on the bed while the roomoccupant moves about, looking for the proper laces for the shoes. Davies' posture of sitting there like a master expresses vividly the transformation in the relationship between them and his dominating feeling towards Aston. By this time, Davies has had the offer from Mick to be the caretaker and he also learns Aston's traumatic experience in the asylumall these seem to give him the reason to trample his former patron as an inferior. His examination of the shoes Aston finds for him is picky and critical: "Well, I'll tell you what, they might do...until I get another pair. (Pause.) Where's the laces? ... I can't wear them without laces"(p.103). After Aston finds laces for him, he is still dissatisfied: "These are brown...These shoes are black" (p.104). After this, the screen becomes a total blackout, which embodies both the crashing of Aston's hope for communication and the blackout of the tramp's prospect in the room. The next minute, the audience finds the final explosion of their conflict and Davis being expelled. By dramatizing the process of how Davies subverts his relationship with Aston by turning the latter's offers into his own demand, the play succeeds in showing the nasty side in the tramp's character.

But the crucial point of the play is that manipulating as Davies is, the image of the old tramp fighting for the "bed" and "room" still wins somehow the sympathy of the audience; after all, he is but a man ensnared in a doomed predicament of eternal "lack". As a man in society, he learns to use intrigues (bully and manipulation) to fight for his territory, but as a social man, he is doomed to suffer the pain of eternal gap between what he wants and what he gets. After accepting Aston's shoes but denying its value, Davies gives an important speech that throws new light on his character:

Maybe they'll get me down to Sidcup tomorrow. If I get down there I'll be able to sort myself out.... (Aston quietly exits, unnoticed.) Don't know as these shoes'll be much good. It's a hard road, I been down there before. Coming the other way, like.... lucky I didn't die there on the road, but I got here, I kept going, all along...yes... I kept going all along. But all the same, I can't go on like this, what I got to do, I got to get back there, find this man-(He turns and look about the room.) Christ! That bastard, he ain't even listening to me! (p.105)

Speeches like this suggest that perhaps Davies should not be simply understood as an imposter or bully. Nor is it simply his bad nature that makes him run down Aston's offers. His relations with the "room" reflect the deadlock of mankind as a whole in his continual fight for his desired object when that object keeps fading away. As he cries bitterly, "I kept going, all along...yes...I kept going all along." In the film, part of this speech is cut off. But a much stronger poignancy about Davies is achieved through the visual effect of the last scene in the film. After Aston tells him firmly that he cannot change beds with him, Davies cries to him: "But you don't understand my meaning! ...Christ, we'll change beds!"'(pp.122-3). While the old man utters this sentence, he is angrily punching his hands again-but this violent gesture conveys more pitiable desperation than menace as critics usually suggest. When his last suggestion of 
sleeping in his own bed is also refused, the close-up shot shows that the man is shivering with fury. His face tries to squeeze a smile, but the smile is more horrible than cry. The final shots shift between Aston's back at the window and the old tramp's helplessly shivering face. Then the screen becomes a total blank soundtracked by sad music.

To a certain degree, the strong feeling of poignancy aroused by the close-up scenes of Davies's facial expressions forms the other aspect of the tramp's dilemma. He demands the bed because it is the "thing" that can end the insecure life on the street, a sanctuary from that "draught" that has characterized his very existence so far. The final scene of the old man standing there, holding his bag and looking in desperation at Aston's back beside the window, articulates the dilemma of Davies the tramp in specific and mankind in general. He needs the "bed" as it is the necessity in life; but by demanding it from another man's hand, he turns himself into a threat to another fellow being. The image of the old man standing before the camera asking for a bed exemplifies the universal situation of men in "need" and "gap". This might be the reason why the tramp would arouse such mixed feelings in the heart of the audience.

Pinter wants to present in Davies the despair of living in the "other place" and the eternally elusive sense of security. Similarly, in The Birthday Party, it is not the external violence that happens on Stanley that Pinter aims to portray-but the deepest horror of "no place to go" and profoundest desire to be left alone. Nicolas in One for the Road is another example of how the dramatist explores the inner reality of his characters. In a 1996 interview, Pinter (1996) made such an explanation about Nicolas: "I recognize the plight he's in. Don't forget Nicolas is a deluded man; he's a man possessed, religiously really. He's enacting a religious and political obsession, and I feel very sorry for him" (Billington, 1999, p.62). In Pinter's eyes, Nicolas is a political villain, but he is also a man whose situation of gap and lack is pushed to an extreme. By portraying the brutality of Nicolas, Pinter examines the psychological complexity of his protagonist - the subconscious impulse to erase the private "I" that can never be fulfilled and to attach himself instead to the social "I" that is defined by the language of society. In Nicolas" "I am not alone" lays not only his pride in the collective power in his hand, but also an ineffable bitterness and desperation for the eternal loss that he feels in his subconscious. In this respect, we can understand why "Nicolas, who seems to have no life outside his official function and who is sustained by the ersatz family of the state, is magnetically drawn to the very people he is bound to destroy" (Billington, 1996, p.295). In torturing his victims, he is unconsciously torturing the real voice of himself whose wholeness he despairs of ever gaining. In Nicolas' character, it is not just malice and jealousy, but something deep in his mind and even unconscious that Pinter is bent on presenting.

\section{DRAMA IN THE INNER REALITY}

However, Pinter's exploration of the inner reality is not limited to figures like Nicolas or Stanley, but to most of his characters (both villains and victims) who are involved in the family hostilities, gender suppressions and political persecutions. In all his plays, there are two levels on which the characters are examined: socially speaking, they can be categorized into villains and victims; but psychologically, they are all just human beings. Their difference lies in which "I"- the social or the private one- they choose. To a certain degree, there seem to be no real villains in Pinter's plays (no matter how "villainous" some characters appear). All the "villains"-Goldberg, Nicolas, Max, Teddy, and the rough Andy_-are but "real men". Pinter implies that there are even some similarities between Shakespeare's tragic heroes and his "villains". In The Dwarfs, the only novel by Pinter, his character Mark makes such a brilliant comment on Shakespeare's characters:

...Othello, Macbeth and Lear, are men whose great virtues are converted by their very superfluity into faults...Othello is jealous because of an excess of love... Macbeth's real trouble was that he thought too much of his wife. The trouble with these people is that they refuse to recognize their own territorial limitations. Their feelings are in excess of the facts. All they're doing is living beyond their means. And when they have to act, not upon their notions but upon their beliefs, they're found to be lacking. When they're called to account by common justice they're wrong. At the same time, of course, they're right. They are right according to our admiration and sympathy. But that's to look at them in no way morally.... We're sympathized with what they are when unhampered by the responsibility of action....

All they can see is the natural process of cause and effect working in a system of which they have ceased to be a part. They fall away from this system by lack of a social virtue.... They try to overcome a machine of which they remain, whether they like it or not, a part. The machine, if you like, is morality, the standards of the majority. It seems to me that Shakespeare justifies both the man and the machine. (pp.132-3)

Here it is more Pinter the author rather than Mark the character who is making this statement about Shakespeare and commenting on the traditional sense of humanity. What Mark criticizes is Shakespeare's blurring of the worlds of their private self and the public one defined by moral "language". To Mark (and Pinter), these heroes are the very specimen of "real men". Their life becomes a tragedy because they refuse to recognize "their own territorial limitations," thereby making their great virtues converted by their very superfluity into faults. That is to say, refusing the "gap" between their private longing for the wholeness and the Symbolic world of society (i.e., all the taboos and morality), they are actually the victims of Lacan's concept of the Other: "when they have to act, not upon their notions but upon their beliefs, they're found to be lacking. When they're called to account by common justice they're wrong." But it is just the faults of the heroes that make them human. It is this basic human situation of being the slaves and victims of "lack" that make Pinter's characters similar to Shakespeare's heroes.

Whatever their behaviors are in the plays, being villains or heroes, "we're sympathized with what they are when 
unhampered by the responsibility of action" (p.133). Maybe the only difference between the villain and the hero is that the former transplants himself thoroughly in the social machine he is in and uses it to balance the lack in his unconscious, while the latter tries "to overcome a machine of which they remain" (p.133). Actually here also lies one of Pinter's political dilemmas: his perception of the origin of the power and brutality as part of human nature, and his moral indignation against all the injustice in the power relations. On the one hand, Pinter suggests that there is no real division between the torturers and victims in the basic instinct for seeking for wholeness and security. What makes them different is their way to seek for it: victims turn to their individual voice of instinct as a positive way to get his sense of wholeness while the "villains" turn to the external world of power as a cynical way to forget their deepest hunger for it. Their remote yet inerasable dream hidden beneath their brutality_Goldberg's illusionary faith in the Dad, Max and Andy's longing for filial love, Nicolas' longing for a life of love-seems to the primordial drive to their brutality. Their failure to have their desires satisfied makes them turn to the tools in the "language" world (either paternal authority or political power) to release those twisted emotions: Goldberg reduces Stanley to another mindless figure like himself, Max reduces Teddy to a brute like himself who bears the loss of family with equal iciness, and Nicolas shatters the family love and independent mind he cannot possess.

It is just this human drama of Lacan's realm of "the Real" that Pinter tries to present: the men who are trapped in various ambivalent forces which turn family love into hatred, and human relations into political persecutions. Presenting the inner reality of his characters, Pinter is dealing with the overlapping realm of the external and internal world, a realm when the characters' private voice from the deepest part of their unconscious collides with the demands of the social force.

\section{REFERENCES}

[1] Billington, Michael. (1996). The life and work of Harold Pinter. London: Faber and Faber.

[2] Bowie, Malcom. (1987). Freud, Proust and Lacan. Cambridge: Cambridge University Press.

[3] Burke, Sean. (1998). The Death and Return of the Author. Edinburgh: Edinburgh University Press.

[4] Donner, Clive. (1963). The Caretaker. The British Film Institute. Film.

[5] Gussow, M. (1994). Conversations with Pinter. New York: Limelight Edition.

[6] Hale, Steven H. (1986). Harold Pinter, Critical Approaches. London: Associated University Presses.

[7] Holland, Eugene W. (1999) Deleuze and Guattari's Anti-Oedipus. London: Routledge.

[8] Nightingale, Benedict. (1981). "Taking Care.” Radio Times. June, 6-12.

[9] Page, Malcolm, (1993). Files on Pinter. London: Methuen Drama.

[10] Pinter, Harold. (1993). Victorian Station. Harold Pinter: Plays Four. London: Faber and Faber.

[11] Pinter, Harold. (1993). A Kind of Alaska. Harold Pinter: Plays Four. London: Faber and Faber.

[12] Pinter, Harold. (1991). The Caretaker. London: Faber and Faber.

[13] Pinter, Harold. (1998). Various Voices, Prose, Poetry, Politics, 1948-1998. London: Faber and Faber.

[14] Wright, Elizabeth. (1984). Psychoanalytic Criticism: Theory in Practice. London: Methuen.

Hongwei Chen was born in Henan, China, on $15^{\text {th }}$ July, 1966. She received her MA and PhD in English and American literature in Beijing Foreign Studies University (1993, 2005), China, and her $2^{\text {nd }}$ MA in English literature in Leeds University (2004), England.

She is a professor of the School of Foreign Studies in Beijing Science and Technology University, teaching various literature and culture courses for the undergraduates, MA and PhD students. She had published in the past several years such academic works as Harold Pinter in the Post-War English Drama (Beijing: University of International Business and Economics Publisher, 2007), History of Contemporary English Drama (second author. Beijing: Beijing University Publisher, 2007), $20^{\text {th }}$ Century English Drama (Beijing: Beijing University Publisher, 2009), Center and Margin: Tom Stoppard the Playwright (being published, Beijing: Beijing University Publisher, 2012). Her current research interest lies in English and Chinese drama. 